\title{
ArcheoSciences
}

Revue d'archéométrie

Authentication and analysis of goldwork

\section{Ancient gold patinas: experimental reconstruction}

Les patines anciennes de l'or : recréation expérimentale

\section{Alessandro Pacini}

\section{OpenEdition}

\section{Journals}

Electronic version

URL: http://journals.openedition.org/archeosciences/2526

DOI: 10.4000/archeosciences. 2526

ISBN: 978-2-7535-1598-7

ISSN: 2104-3728

Publisher

Presses universitaires de Rennes

\section{Printed version}

Date of publication: 31 December 2009

Number of pages: 393-396

ISBN: 978-2-7535-1181-1

ISSN: $1960-1360$

\section{Electronic reference}

Alessandro Pacini, « Ancient gold patinas: experimental reconstruction», ArcheoSciences [Online],

33 | 2009, Online since 10 December 2012, connection on 19 April 2019. URL : http://

journals.openedition.org/archeosciences/2526 ; DOI : 10.4000/archeosciences.2526 


\title{
Ancient gold patinas: experimental reconstruction
}

\author{
Les patines anciennes de l'or : recréation expérimentale
}

\author{
Alessandro PACINI*
}

\begin{abstract}
The present study is based on the experimental reconstruction of samples of different carat gold foil, obtained by hand hammering, and subsequently subjected to different physical-chemical treatments with the aim of reproducing ancient patinas. The treated samples were then analysed by SEM-EDS in order to provide a valid comparison with the ancient goldsmiths' techniques.
\end{abstract}

Résumé : Ce travail se base sur la recréation expérimentale d'échantillons de feuilles d'or réalisées par martelage à la main et dont la composition en carats est variée. Ces feuilles sont ensuite soumises à divers traitements physico-chimiques pour reproduire des patines anciennes. Les échantillons subissant ces traitements ont été analysés par MEB-EDS de façon à obtenir une comparaison valide avec les techniques orfevres anciennes.

Keywords: Patina, gold patination, colouring, giallone, gilding

Mots-clés : patine, patine d'or, coloration, giallone, dorure.

\section{INTRODUCTION}

In the field of the recognition of fakes in jewellery, the laboratory An.te.a. deals with the typical patinas of archaeological jewellery. In general, such objects can be recognized by four typical patinas:

Natural patinas due to the contact of the jewellery with earth, water or air.

Non-intentional patinas from contact with substances associated with the life of the jewellery (blood, perfume, etc.).

Restoration patinas (due to the process of cleaning).

Artificial patinas with the aim of forgery.

The major part of jewellery patinas are caused by liquation and alteration of the copper and silver contained in the alloy and/or superficial deposits of corrosive products, soil, or decomposed organic material. Rarely, in particular conditions related to the position in which the object is deposited, alterations to the gold itself can also be verified, caused by the formation of gold cyanide or complex compounds with chlorine, (Grimwade, 1999; Mazzeo, 2005) which result in an orangey-brown patina. The colours and effects of ancient jewellery patinas have always been the subject of imitation on the part of the jewellers who, in various eras, have tried to reproduce archaeological jewellery. In order to better identify these artificial patinas, we carried out a reproduction of patination via chemical processes on some gold samples, based on old laboratory recipes. The results were then submitted to an SEM-EDS analysis by Daniela Ferro at the Institute for the Study of Nanostructured Materials (CNR-ISMN) in Rome.

\section{EXPERIMENTATION}

The samples were made up of sheets $1 \mathrm{~cm}$ wide and 0.1 mm thick, obtained by hammering $(\mathrm{M})$ and by a rolling mill (L). Three types of alloys similar to the ancient ones

* An.te.a. - Laboratory of archaeometry and experimental archaeology. (ale.pacini@gmail.com) 
have been used: Alloy A = Au 95\%, Ag 4\%, Cu 1\%; Alloy $\mathrm{B}=\mathrm{Au} 93 \%$, Ag 5\%, Cu 2\%; Alloy C = Au 90\%, Ag 7\%, $\mathrm{Cu} 3 \%$. The samples are classified by: letter of the alloy (A, $\mathrm{B}$ or $\mathrm{C})$, type of work ( $\mathrm{M}$ or $\mathrm{L})$, and identification number (1, 2 or 3$)$.

Some gold samples have been buried for 30 days at $16^{\circ} \mathrm{C}$ in soil rich in organic substances, moistened with water, ammonia and blood, and submitted every seven days to a heat of $100{ }^{\circ} \mathrm{C}$ for an hour. At the end of the 30 days period, only one sample presented a superficial change with small red spots, and part of the surfaces had a dark yellow colour. A very intense colouring of the surface of sample CM2 was caused by pickling in a boiling solution of iron sulphate, ammonium chloride, sodium thiosulphate and potassium bitartrate in distilled water. The sample was subsequently heated over a flame, resulting in a toning down of the bright colours (Fig. 1). Sample AM1 was painted with a red iron oxide suspension in distilled water, lightly heated over a flame, and then cooled in water (Fig. 2). Sample BM3 was painted with an iron sulphate suspension in distilled water, heated to red by a flame and cooled in water, and then brushed (Fig. 3).

Colouring is a process that can be performed on jewellery items with the purpose of forgery, by pickling, which dissolves the less precious metals on the surface of the jewellery, leaving a few microns of thickness of pure gold. Classical

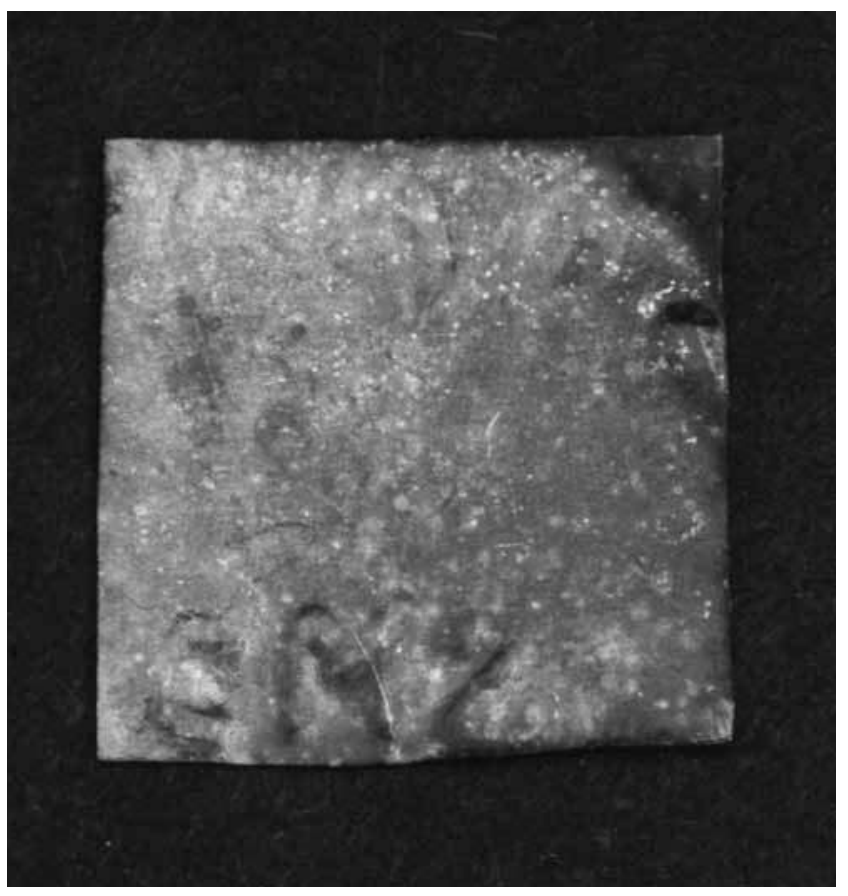

Figure 1: (See colour plate) Sample CM2.

Figure 1: (Voir planche couleur) Échantillon CM2.

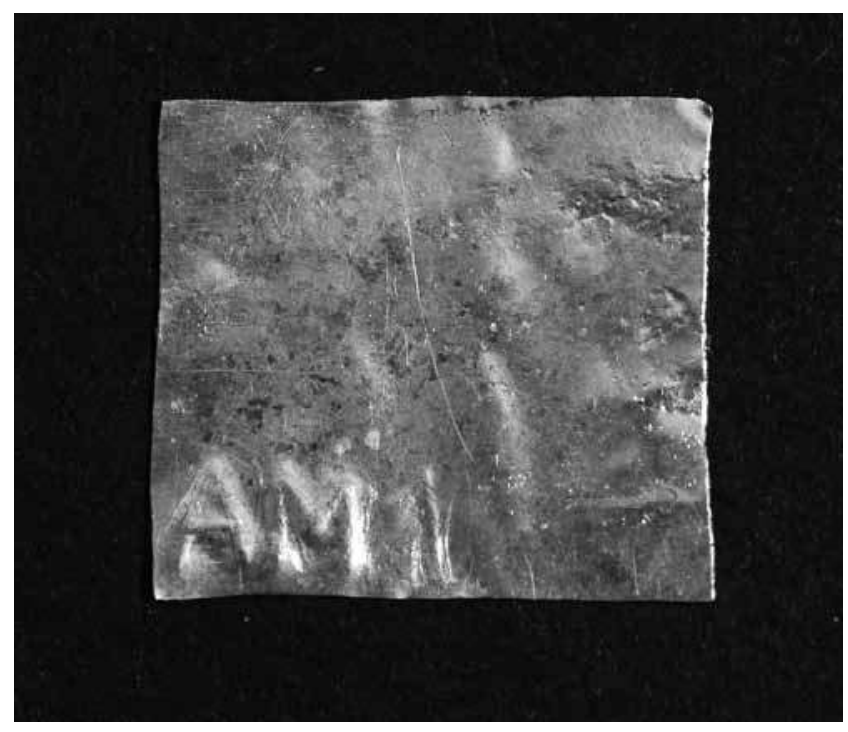

Figure 2: (See colour plate) Sample AM1.

Figure 2: (Voir planche couleur) Échantillon AM1.

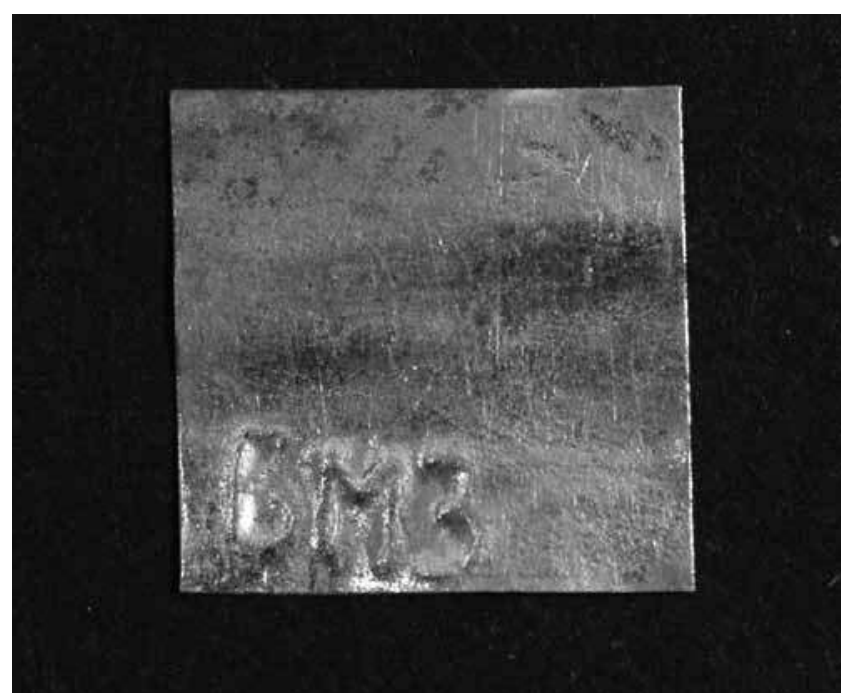

Figure 3: (See colour plate) Sample BM3.

Figure 3: (Voir planche couleur) Échantillon BM3.

pickling is carried out with a watery solution of sodium chloride, potassium nitrate and alum, but there are also very ancient recipes (for example No. 67 of the Leiden Papyrus Caffaro and Falanga, 2004) for colouring jewellery. Sample BL1 was immersed for a few seconds in a solution of boiling water, hydrochloric acid, saltpetre and sodium chloride, in order to obtain the typical opaque surface and light corrosion associated with antique jewellery.

Around the middle of the $19^{\text {th }}$ century, the archaeological jewellery of Castellani was coloured by using chemical baths 
to obtain the famous "giallone" of Etruscan gold (Castellani, 1827: 161-164), also employed in this case as a treatment to enrich the surface with a chemical gilding. The colouring was caused by dissolving the metal alloys on surfaces, or it could also be carried out (better on low carat gold, as in the case of tumbaga) by boiling the article in an acid vegetable juice, such as that of the plant Rumex acetosa, or in a solution of salt and vinegar. The colourings, in archaeological fakes, serve above all to uniform the colour of the surface, hiding the eventual brazing made with alloys richer in silver, and thus the resulting lighter colour.

The soil deposits often present in antique jewellery are imitated by using a very fine clay mixed with resin or vegetable paste, easily recognizable by the uniform distribution on the precious piece and its light consistency.

\section{RESULTS OF THE ANALYSIS ON SAMPLES AM1 AND BM3}

\section{AM1}

The surface observed by SEM using backscattered electrons highlights a structure with well formed crystal grains with a darker inter-granulated area. The subsequent EDS microanalysis carried out on the areas indicated in the illustration (Fig. 4) revealed the values of the elements reported in Table 1. In area No. 1, the composition corresponds to the initial alloy, while in the inter-granulated area there is evidence of a decrease of silver and copper, and of the simultaneous formation of ferrous composites. The other minor

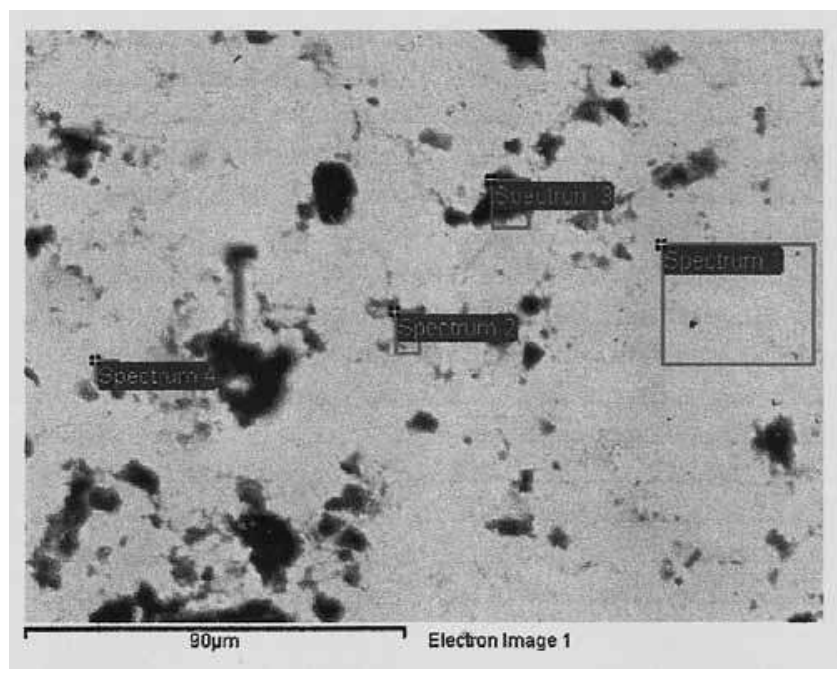

Figure 4: EDS microanalysis of sample AM1.

Figure 4: Micro-analyse EDS de l'échantillon A1.

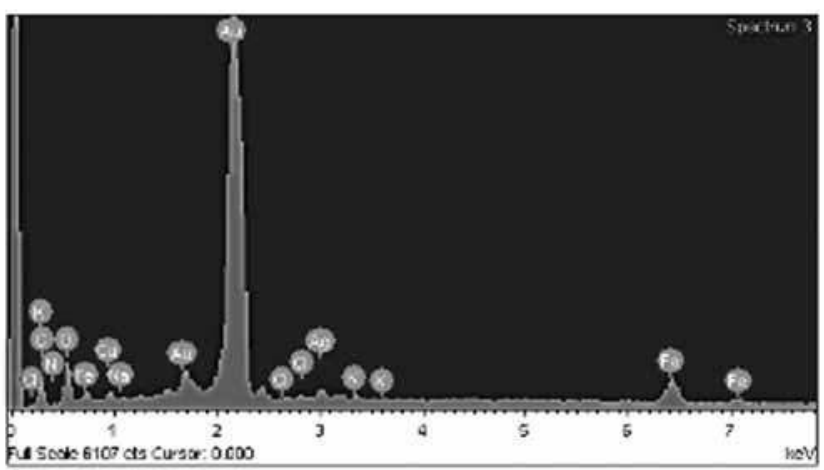

Figure 5: X-ray EDS spectrum of sample AM1.

Figure 5 : Spectre de rayons X par EDS de l'échantillon AM1.

elements are the ochre components and the other products used in the experimental procedure.

A part of the qualitative spectrum highlights the iron peak, while the other elements of ochre are a little more higher than the background; this observation could allow us to put forth the hypothesis of the formation of the ferric oxide as being responsible for the rose colouring of the patina (Fig. 5).

\section{BM3}

The superficial morphology highlights a rough aspect, almost spongy, with some formation of crystals. The EDS analysis on the area indicates a square figure, elaborate in respect of the single elements of the golden alloy, revealing an impoverishment only of the silver, probably due to the formation of the silver sulphide then taken from the surfaces (Fig. 6).

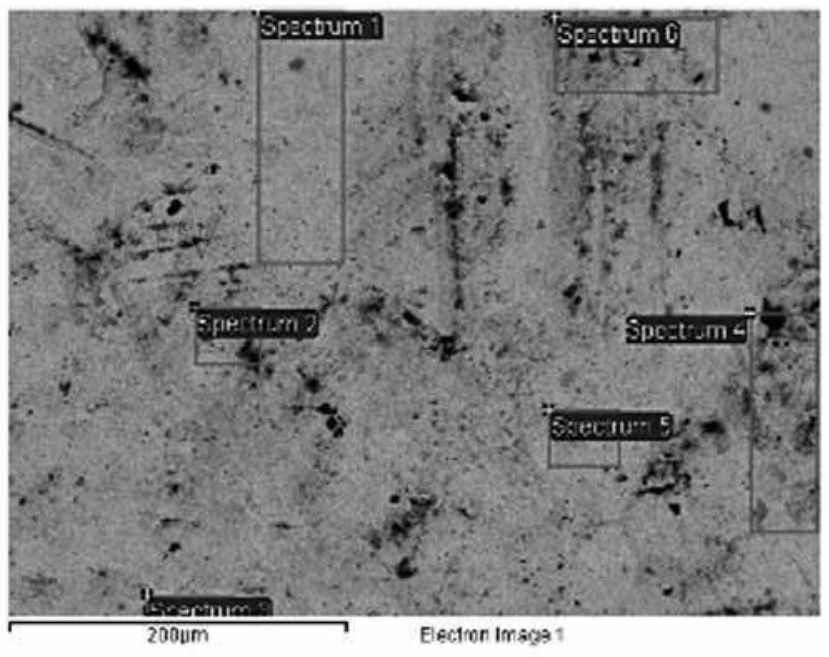

Figure 6: EDS microanalysis of sample BM3.

Figure 6: Micro-analyse EDS de l'échantillon BM3. 


\begin{tabular}{|c|c|c|c|c|c|c|c|c|c|c|c|c|}
\hline Area & $\mathrm{C}$ & $\mathrm{O}$ & $\mathrm{Na}$ & $\mathrm{Mg}$ & $\mathrm{Al}$ & $\mathrm{Si}$ & $\mathrm{K}$ & $\mathrm{Ca}$ & $\mathrm{Fe}$ & $\mathrm{Cu}$ & $\mathrm{Ag}$ & $\mathrm{Au}$ \\
\hline 1 & & & & & & & & & & 0.54 & 3.50 & 95.95 \\
\hline 2 & 30.11 & 11.18 & 0.08 & 0.19 & 0.21 & 0.5 & 0.18 & 0.78 & 0.31 & 0.54 & 1.88 & 53.90 \\
\hline 3 & 40.79 & 13.13 & 0.21 & 0.19 & 0.48 & 1.5 & 0.29 & 1.81 & 0.39 & 0.43 & 1.26 & 39.05 \\
\hline 4 & 8.75 & 23.21 & 0.18 & 1.01 & 1.15 & 2.64 & 0.15 & 0.28 & 0.95 & 0.49 & 2.14 & 58.23 \\
\hline
\end{tabular}

Table 1: Composition of sample AM1; concentrations are given in $\mathrm{wt} \%$.

Tableau 1 : Composition de l'échantillon AM1 ; concentrations en \%.

\begin{tabular}{|c|c|c|c|c|c|c|c|c|c|c|}
\hline Spectrum & $\mathrm{C}$ & $\mathrm{N}$ & $\mathrm{O}$ & $\mathrm{Na}$ & $\mathrm{Cl}$ & $\mathrm{K}$ & $\mathrm{Fe}$ & $\mathrm{Cu}$ & $\mathrm{Ag}$ & $\mathrm{Au}$ \\
\hline 1 & 7.84 & 2.73 & 2.91 & & & & 0.63 & 1.51 & 2.97 & 81.40 \\
\hline 2 & 15.36 & & 13.35 & & & & 4.58 & 1.76 & 2.63 & 62.33 \\
\hline 3 & 29.13 & & 10.13 & 0.5 & 0.77 & 0.53 & 1.69 & 0.87 & 2.04 & 54.34 \\
\hline 4 & 15.20 & & 11.03 & & 0.3 & & 3.18 & 1.69 & 2.27 & 66.33 \\
\hline 5 & 9.42 & & 6.84 & & & & 1.74 & 1.75 & 2.61 & 77.64 \\
\hline 6 & 8.88 & 3.18 & 11.27 & & & & 3.08 & 1.47 & 2.58 & 69.54 \\
\hline
\end{tabular}

Table 2: Composition of sample BM3; concentrations are given in $\mathrm{wt} \%$.

Tableau 2 : Composition de l'échantillon BM3 ; concentrations en \%.

Table 2 presents the composition (in terms of weight percent) of all the elements present, showing the presence of iron in noticeable quantity, and thus attesting the formation of a red colour ferric product (oxide).

\section{Conclusion}

The processes effected on the two samples analysed produced a red colour similar to that of the natural patina, but which is however different, due to the lack of significant alterations to the golden alloy underneath the iron oxide. This type of artificial patinas can therefore be revealed by analytical methods.

\section{References}

Castellani, A., 1827. Sul pulimento dell'oro. Antologia, giornale di scienze, lettere e arti XXV: 161-164.

Caffaro, A. and Falanga, G., 2004. Il papiro di Leida: un documento di tecnica artistica e artigianale dell'IV secolo d.C. Salerno, Arci ed., Postiglione.

Grimwade, M., 1999. Arricchimento superficiale delle leghe d'oro per gioielleria. Gold technology 26: 16-23.

Mazzeo, R., 2005. Patine su manufatti metallici, in Le patine: genesi, significato e conservazione. Nardini ed., Firenze, Kermesquaderni, 29-43. 